\title{
On the orders of magnitude of epigenic dynamics and monoclonal antibody production
}

\author{
J. M. Savinell, G. M. Lee and B. O. Palsson, Ann Arbor
}

\begin{abstract}
The hybridoma cell's maximum capacity for monoclonal antibody $(M A b)$ production is estimated to be $2300-8000 \mathrm{MAb}$ molecules/cell/s, using measured rates of transcription and translation, and the limitations imposed by the size of the polymerase molecule and the ribosome. Nearly all the production rates reported in the literature fall into or below this range of production rates. Data from batch cultures of hybridomas demonstrate a constant specific rate of $M A b$ production until the time integral of the viable cell concentration reaches about $10^{8} \mathrm{cells} \cdot \mathrm{h} / \mathrm{cm}^{3}$. At this point, some essential nutrients from the standard media are depleted, causing $M A b$ production to decline.
\end{abstract}

\section{Introduction}

Rapidly growing markets for monoclonal antibodies ( $M A b s)$ have brought about the large-scale cultivation of hybridomas and the development of optimal processing schemes. The preliminary analysis needed for process design requires us to seek order of magnitudes of key rates, capacities, and other necessary data for orientation and identification of factors that need quantitative analysis. Herein we attempt to establish how basic biochemical and cellular determinants set the order of magnitude of the rate of monoclonal antibody production. Our order of magnitude estimate is consistent with experimental observations.

\section{Dynamics of antibody synthesis}

Antibody synthesis in hybridoma cells proceeds in a sequence of several well-known steps, shown in Fig. 1. These steps are transcription, processing of the heteronuclear RNA $(h n R N A)$, translation, assembly of polypeptides and their glycosylation, and secretion of the antibody. Antibody accounts for a large fraction of protein synthesized in $A b$-producing cells. For instance, in rapidly growing MOPC 21 and MPC 11 myeloma cells, a single gene for each of the heavy $(H)$ and light $(L)$ chains may provide enough $m R N A$ that leads to about $20-30 \%$ of the protein synthesized [1].

We will now estimate the theoretical maximum rate of antibody synthesis, which is the steady state flux through the $A b$ production system. ${ }^{1}$ These order of magnitude calculations will give an upper bound on the specific productivity of hybridoma cells, and are based on the cell's capacity for transcription and translation. ${ }^{2}$ The maximum capacity for the other stages of $A b$ synthesis, such as glycosylation and secretion, are more difficult to evaluate at present. However, these steps would only serve to reduce our estimate of the maximum $A b$ synthesis rate, if they would prove to be capacity limiting. As will be shown below, the estimate based on the processes of transcription and translation agrees with experimental data.

A dynamic mass balance on the cytoplasmic $A b m R N A$ concentration is:

$\frac{\mathrm{d}[m R N A]}{\mathrm{d} t}=\frac{v_{c}}{s_{c}} \cdot D \cdot E-k \cdot[m R N A]-\mu \cdot[m R N A]$,

where $[m R N A]$ is the number of $m R N A$ per cell in the cytoplasm, $D$ is the gene dosage, which for hybridomas is equal to one gene per cell; $E$ is the fraction of nuclear $m R N A$ which reaches the cytoplasm; $v_{c}$ is the velocity of the polymerase II molecule in nucleotides/s/gene; $s_{c}$ is the spacing of nucleotides between polymerase molecules on the DNA, with units nucleotides/polymerase; $k$ is the degradative rate constant related to the half life of $m R N A$, in $\mathrm{s}^{-1} ; \mu$ is the growth rate, in $\mathrm{s}^{-1}$.

Assuming that in balanced growth, the amount of $m R N A$ per cell is in a quasi-steady state, we obtain

$[m R N A]_{s s}=\frac{v_{c} \cdot D \cdot E}{s_{c} \cdot k} \cdot \frac{1}{1+\frac{\mu}{k}}$.

1 Such an estimate should not be confused with the characteristic response times associated with the individual steps in the process. For example, the response time, defined as the approximate length of time for the process to occur, is $20-150 \mathrm{~min}$ for the glycosylation/secretion step $[2,3]$, and $40 \mathrm{~min}$ for nuclear processing [4]. Although these may be the steps in the $A b$ synthesis pathway with the slowest response times, they do not necessarily limit the cell's capacity for $A b$ synthesis.

2 Similar calculations have been used to estimate the rate of zymogen synthesis in cocoonase zymogen cells [5]. 


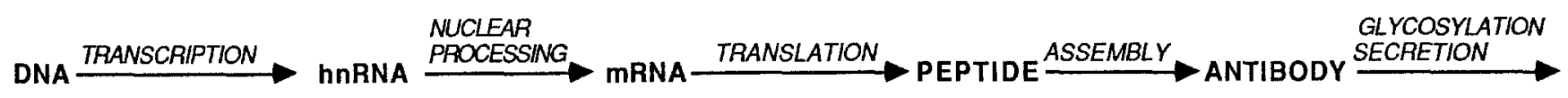

Fig. 1. Pathway of antibody synthesis

The various parameters appearing in this expression may be estimated from the available literature. Reported values for $v_{c}$ are 83 nucleotides/s for HeLa ribosomal RNA [6], 67 in poliovirus [7], and 45 in E. coli [8]. The reported values for $s_{c}$ are 75 nucleotides/polymerase in E. coli [9], and 79-92 in Triturus viridescens [10]. Based on the physical size of the polymerase II molecule, the minimum spacing is about 38 nucleotides [10], although it is unlikely that this spacing can be physically achieved. Approximately $70-90 \%$ of the $h n$ RNA produced in the nucleus is transported to the cytoplasm [11], so $E$ falls in the range of $0.7-0.9$. The average half-life of $A b m R N A$ has been measured to be $12 \mathrm{~h} \mathrm{[12],}$ corresponding to a $k$ value of $1.61 \cdot 10^{-5} \mathrm{~s}^{-1}$. Minimum doubling times for hybridomas are on the order of $12-14 \mathrm{~h}$ and $\mu$ is therefore less than or equal to $k$. Consequently, the factor $\frac{1}{1+\frac{\mu}{k}}$ falls in the range $0.5-1.0$. For doubling times of $14-20 \mathrm{~h}$, this factor takes values in the range of $0.54-0.63$. Using the parameter values most appropriate for myeloma cells, we obtain the estimated range for $[m R N A]_{s s}$ :

$$
\begin{aligned}
& {[m R N A]} \\
& \quad=\frac{(83 \text { nucleotides } / \mathrm{s}) \cdot(0.7 \text { to } 0.9)}{(80 \text { nucleotides/polymerase })\left(1.61 \cdot 10^{-5} \mathrm{~s}^{-1}\right)} \cdot(0.5 \text { to } 1.0) \\
& \quad=23,000 \text { to } 58,000 \mathrm{H} \text { or } L m R N A \text { molecules/cell } .
\end{aligned}
$$

The reported estimates of 54,000 $L m R N A /$ cell [11], and $40,000 L m R N A$ and $30,000 H m R N A$ [13] fall within this range. The upper limit for the $[m R N A]_{s s}$ can be extended to $122,000 \mathrm{mRNA}$ molecules/cell if the minimum polymerase spacing of 38 nucleotides/polymerase is used.

The equation for translation of $A b m R N A$, assuming that translation is a first order process [14], is:

$V_{A b}=\frac{1}{2} \cdot \frac{v_{s}}{s_{s}} \cdot[m R N A]_{s s}$.

We assume that the ribosome concentration is not limiting and, therefore, the translation rate is independent of ribosome concentration. Reported values for the ribosome velocity, $v_{s}$, are 20 nucleotides/s in myeloma [1], 25 in reticulocytes [15], and 48-60 in Salmonella typhinurium [16]. The number of nucleotides between ribosomes, $s_{s}$, is reported to be 90-100 in myeloma [1] and reticulocytes [15], and 88-99 in somatotropes and mammotropes [17]. The factor of 0.5 occurs because two $H$ and two $L$ polypeptide chains are needed for the assembly of one complete $A b$ molecule. To estimate the maximum $A b$ production rate, we have neglected the turnover of either the $H$ or $L$ chains. The $H$ chains are believed to be relatively stable, while the $L$ chains can exhibit significant turnover $-L$ chains are reported to be produced in excess of $H$ chains [3]. The rate of $H$ chain synthesis thus forms a suitable upper bound on the $M A b$ excretion rate.

The range of the maximum $A b$ synthesis rate can then be calculated using Eq. (3) with the parameter values appropriate for the myeloma cell, and the $m R N A$ concentrations that were calculated previously:

$$
\begin{aligned}
V_{A b} & =\frac{1}{2} \cdot \frac{20 \text { to } 25 \text { nucleotides } / \mathrm{s}}{90 \text { to } 100 \text { nucleotides } / \text { ribosome }} \\
& \cdot(23,000 \text { to } 58,000 \mathrm{mRNA} / \mathrm{cell})=2300 \text { to } 8000 \mathrm{Ab} / \mathrm{cell} / \mathrm{s} .
\end{aligned}
$$

Therefore, based on the physical constraints enumerated above (the observed polymerase and ribosome packing density, and transcription and translation velocities), the theoretical maximum output of antibody from a myeloma cell is on the order of $2300-8000 \mathrm{Ab}$ molecules/cell/s. If the maximum estimated value of $122,000 \mathrm{mRNA} /$ cell is used, the upper limit for the $A b$ production rate becomes $17,000 A b$ molecules/cell/s.

\section{Discussion}

The reported values of $M A b$ production range from 17 to $8000 \mathrm{Ab} / \mathrm{cell} / \mathrm{s}$ for various hybridoma cell lines (Table 1 ), with most values falling in the range of 500-3000. Our estimate of the maximum rate seems, therefore, reasonable. Fig. 2 shows the normalized $M A b$ concentration plotted against the time integral of the viable cell concentration, for several sets of batch data reported in the literature. The slope of this curve, which gives the specific productivity, is nearly linear up to the point around $10^{8}$ cells $\cdot \mathrm{h} / \mathrm{cm}^{3}$ for all the data used. At this point, one or more critical components seem to be depleted from the standard media, causing the $M A b$ production to decline [18]. It has been shown that when the essential amino acids were added to the media at this point, the cells continued to synthesize antibody at the same rate [18]. Figure 2 indicates that the specific productivity of $M A b$ is nearly constant at the individual cell line's characteristic rate, as long as the necessary nutrients are available. All these data sets come from experiments with $5-10 \%$ serum in the media. Data from our laboratory show that the specific $M A b$ production rate is serum independent [19], except under long term adaptation to very low serum levels (unpublished results).

The high $M A b$-producing hybridoma cell lines, shown in Table 1, secrete $M A b$ at rates that are close to our estimated capacity of the epigenic system. If nutritional conditions are 


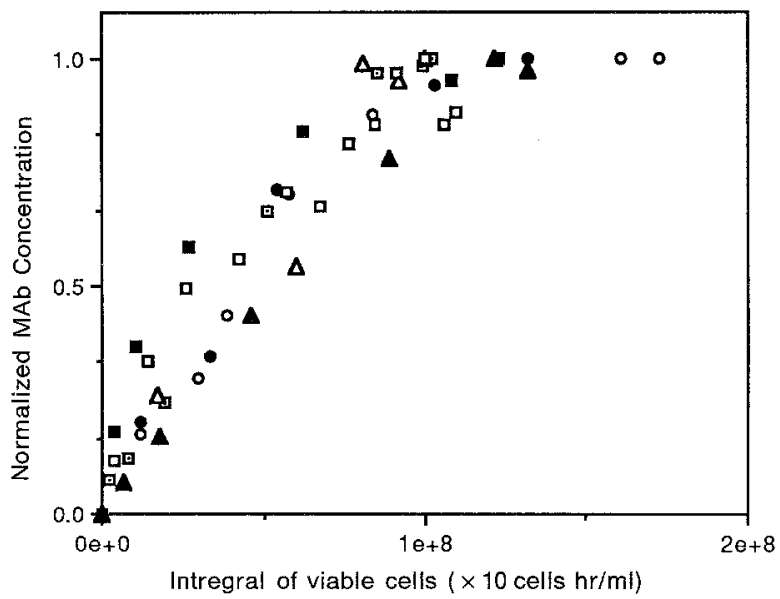

Fig. 2. Antibody concentration plotted against the time integral of the cell concentration, for cells grown in batch cultures. The antibody concentrations are normalized against the maximum antibody concentration for that cell line. Sources of the data are: $\square$ [20]; $\bullet$, o [21]; $\Delta[22] ; \mathbf{m}[23] ;$ 口 [24]; $\Delta[25]$

Table 1. Reported antibody production rates

\begin{tabular}{|c|c|c|}
\hline Cell line & $\begin{array}{l}\mathrm{Ab} \text { production rate } \\
\text { molecules } / \mathrm{cell} / \mathrm{s}\end{array}$ & $\begin{array}{l}\text { Refer- } \\
\text { ence }\end{array}$ \\
\hline \multicolumn{3}{|l|}{ Batch } \\
\hline mouse HB8178, IgG & $1200-2700$ & {$[26]$} \\
\hline mouse VII H-8, IgG2a & 580 & {$[27]$} \\
\hline mouse VII $\mathrm{H}-8, \operatorname{IgG} 2 \mathrm{a}$ & $530-4650$ & {$[28]$} \\
\hline mouse $65 / 26, \operatorname{IgG} 2 b / x$ & 480 & {$[29]$} \\
\hline mouse $455, \operatorname{IgG} 2 \mathrm{a}$ & $17-33$ & {$[30]$} \\
\hline mouse B103, IgG & 6000 & {$[31]$} \\
\hline mouse MRC Ox-19, IgG & $470-790$ & {$[32]$} \\
\hline mouse N-527 IgG & 8000 & {$[33]$} \\
\hline mouse J4C2 IgG1 & 830 & {$[20]$} \\
\hline mouse HB $32 \operatorname{IgG} 2 \mathrm{aK}$ & $355-470$ & [18] \\
\hline mouse $9.2 .27 \mathrm{IgG} 2 \mathrm{a}$ & 2230 & {$[22]$} \\
\hline mouse IgG & 970 & {$[25]$} \\
\hline mouse $\mathrm{S} 3 \mathrm{H} 5 / \gamma \mathrm{bA} 2, \mathrm{IgG} 2 \mathrm{bA}$ & 210 & {$[24]$} \\
\hline \multicolumn{3}{|l|}{ Semi-continuous } \\
\hline mouse VII H-8, IgG2a & $490-750$ & {$[28]$} \\
\hline human HF10B4, IgM & 62 & {$[34]$} \\
\hline \multicolumn{3}{|l|}{ Continuous } \\
\hline mouse VII H-8, IgG2a & $460-1400$ & {$[28]$} \\
\hline mouse $65 / 26, \operatorname{IgG} 2 \mathrm{~b} / \varkappa$ & $80-2550$ & [29] \\
\hline mouse N-146, IgG & 5800 & [33] \\
\hline mouse N-226, IgG & 615 & [33] \\
\hline mouse N-527, IgG & 7640 & [33] \\
\hline mouse S-6, IgG & 1210 & [33] \\
\hline mouse S-84, IgM & 380 & [33] \\
\hline rat $R 33-18-12$ & 2460 & [33] \\
\hline rat $\mathrm{R} 33-24-12$ & 110 & [33] \\
\hline rat $\mathbf{R} 33-60$ & 675 & [33] \\
\hline rat IM/41 & 3400 & [33] \\
\hline rat $\mathrm{C} 2-23$ & 2330 & [33] \\
\hline mouse $143, \operatorname{IgG} 2 \mathrm{a}$ & $330-670$ & {$[35]$} \\
\hline mouse NB1, IgM & 60 & {$[36]$} \\
\hline
\end{tabular}

not limiting, improvements in the specific $M A b$ production rate will not be achieved through improved processing technology but rather through modification of cellular components. At present it is uncertain how successfully we can manipulate the cell's protein synthesis machinery.

Our results, therefore, support the view that economically successful large-scale cultivation of hybridomas is likely to depend primarily on the selection of: 1) a high producer, and 2) a processing scheme that supports high cell densities.

\section{Acknowledgements}

The authors acknowledge support for this research from the National Science Foundation grant EET-8712756 and from the Presidential Initiatives Fund at the University of Michigan grant 135-PIS.

\section{References}

1. Potter, M.: Immunoglobulin producing tumors and myeloma proteins of mice. Physiol. Rev. 52 (3) (1972) 631-719

2. Choi, Y. S.: Biosynthesis and secretion of immunoglobulins. In: Litman, G. W.; Good, R. A. (Eds.): Comprehensive Immunology, Vol. 5, Immunoglobulins pp. 345-355. New York: Plenum Medical Book Co. 1978

3. Scharff, M. D.: The synthesis, assembly, and secretion of immunoglobulin: a biochemical and genetic approach. The Harvey Lectures 69 (1973) 125-142

4. Baumal, R.; Scharff, M. D.: Synthesis, assembly and secretion of globulin by mouse myeloma cells. V. Balanced and unbalanced synthesis of heavy and light chains by IgG-producing tumors and cell lines. J. Immunol., 111 (2) (1973) 448-456

5. Kafatos, F. C.: The cocoonase zymogen cells of silk moths: a model of terminal cell differentiation for specific protein synthesis. Current Topics in Developmental Biology 7 (1972) 125-191

6. Greenberg, H.; Penman, S.: Methylation and processing of ribosomal RNA in HeLa cells. J. Mol. Biol. 21 (1966) 527-535

7. Darnell, J. E.; Girard, M.; Baltimore, D.; Summers, D. F.; Maizel, J. V.: The synthesis and translation of poliovirus RNA. In: Colter, J. S.; Paranchych, W. (Eds.): The Molecular Biology of Viruses, pp. 375-401. New York: Academic Press 1967

8. Rose, J.; Mosteller, R.; Yanofsky, C.: Tryptophan messenger ribonucleic acid elongation rates and steady-state levels of tryptophan operon enzymes under various growth conditions. J. Mol. Biol. 51 (1970) $541-550$

9. Miller, O.; Hamkalo, B.; Thomas, C., Jr.: Visualization of bacterial genes in action. Science 169 (1970) 392-395

10. Miller, O.; Beatty, B.; Hamkalo, B.; Thomas, C.: Electron microscopic visualization of transcription. Cold Spring Harbor Symposia on Quantitative Biology 35 (1970) 505-512

11. Gilmore-Herbert, M.; Wall, R.: Nuclear RNA precursors in the processing pathway to MOPC $21 \%$ light chain messenger RNA. J. Mol. Biol. 135 (1979) 879-891

12. Kuehl, W.: Synthesis of immunoglobulin in myeloma cells. Cur. Top. Microbiol. Immunol. (1977) 1-46

13. Schibler, U.; Marcu, K. B.; Perry, R. P.: The synthesis and processing of the messenger RNAs specifying heavy and light chain immunoglobulins in MPC-1 cells. Cell 15 (1978) 14951509

14. Wall, R.; Kuehl, M.: Biosynthesis and regulation of immunoglobulins. Ann. Rev. Immunol. 1 (1983) 393-422

15. Hunt, T.; Hunter, T.; Munro, A.: Control of haemoglobin synthesis: rate of translation of the messenger RNA for the $\alpha$ and $\beta$ chains. J. Mol. Biol. 43 (1969) 123-133 
16. Engbaek, F.; Kjeldgaard, N.; Maaloee, O.: Chain growth rate of beta-galactosidase during exponential growth and amino acid starvation. J. Mol. Biol. 75 (1) (1973) 109-118

17. Christensen, A.; Kahn, L.; Bourne, C.: Circular polysomes predominate on the rough endoplasmic reticulum of somatotropes and mammotropes in the rat anterior pituitary. Amer. J. Anat. 178 (1987) $1-10$

18. Luan, Y.; Mutharasan, R.; Magee, W: Strategies to extend longevity of hybridomas in culture and promote yield of monoclonal antibodies. Biotechnol. Lett. 9 (10) (1987) 691-696

19. Ozturk, S.; Lee, G. M.; Huard, T. K.; Palsson, B. O.: Effect of serum concentration on hybridoma cell growth and monoclonal antibody production at various initial cell densities. Hybridoma 8 (1989) $369-375$

20. Renard, J.; Spagnoli, R.; Mazier, C.; Salles, M.; Mandine, E.: Evidence that monoclonal antibody production kinetics is related to the integral of the viable cells curve in batch systems. Biotechnol. Lett. 10 (2) (1988) 91-96

21. Luan, Y.; Mutharasan, R.; Magee, W.: Effect of various glucose/ glutamine ratios on hybridoma growth, viability and monoclonal antibody formation. Biotechnol. Lett. 9 (8) (1987) 535538

22. Lebherz, W. B.: Batch production of monoclonal antibody by large-scale suspension culture. BioPharm, Febr. (1988) 22-32

23. Seaver, S. S.; Rudolph, I. L.; Gabriels, J. E.: A rapid HPLC technique for monitoring amino acid utilization in cell culture. BioTechniques Sept./Oct. (1984) 254-260

24. Lee, G.; Huard, I.; Palsson, B. O.: The effect of mechanical agitation on hybridoma cell growth. Biotechnoi. Lett 10 (1988) $625-628$

25. Miller, W; Blanch, H; Wilke, C.: A kinetic analysis of hybridoma growth and metabolism in batch and continuous suspension culture: effect of nutrient concentration, dilution rate and pH. Biotechnol. Bioeng. 32 (1988) 947-965

26. Hu, W.; Dodge, T;; Frame, K.; Himes, V.: Effect of glucose on the cultivation of mammalian cells. Dev. Biol. Stand. 66 (1987) 279 290

27. Reuveny, S.; Velez, D.; Macmillan, J.; Miller, L.: Factors affecting cell growth and monoclonal antibody production in stirred reactors, J. Immunol. Methods 86 (1986) 53-59

28. Reuveny, S.; Velez, D.; Miller, L.; Macmillan, J.: Comparison of cell propagation methods for their effect on monoclonal antibody yield in fermentors. J. Immunol. Methods 86 (1986) 61-69
29. Altshuler, G.; Dziewulski, D.; Sowek, J.; Belfort, G.: Continuous hybridoma growth and monoclonal antibody production in hollow fiber reactors-separators. Biotechnol. Bioeng. 28 (1986) $646-658$

30. Tharakan, J. P.; Chau, P. C.: IgG production kinetics in serumfree media. Biotechuol. Lett. 8 (8) (1986) 529-534

31. Merton, O.; Reiter, S.; Himmler, G.; Scheirer, W.; Katinger, H.: Production kinetics of monoclonal antibodies. Dev. Biol. Stand. 60 (1985) 219-227

32. Dalili, M.; Ollis, D. F.: Transient kinetics of hybridoma growth and monoclonal antibody production in serum-limited cultures. In: Proceedings of the American Chemical Society Meeting, 1987

33. de St. Groth, S. F: Automated production of monoclonal antibodies in a cytostat. J. Immunol. Methods 57 (1983) 121-136

34. Murakami, H.; Shimomura, T.; Ohashi, H.; Hashizume, S.; Tokashiki, M.; Shinohara, K.; Yasumoto, K.; Nomoto, K.; Omura, H.; Serum-free stirred culture of human-human hybridoma lines. In: Murakami, H.; Yomane, I.; Barnes, D. W.; Mather, J. P.; Hagashi, I., Sato G. H. (Eds.): Growth and Differentiation of Cells in Defined Environment, pp 111-116. Berlin, Heidelberg, New York, Tokyo: Springer 1985

35. Miller, W; Wilke, C.; Blanch, H.: Kinetic analysis of hybridoma growth in continuous suspension culture. In: Proceedings of the American Chemical Society Meeting, New Orleans, 1986

36. Birch, J; Thompson, P.; Lambert, K.; Boraston, R.: The large scale cultivation of hybridoma cells producing monoclonal antibodies. In: Feder, J.; Tolbert, W. (Eds.): Large-Scale Mammalian Cell Culture, pp. 1-18. St. Louis: Academic Press 1985

Received August 15, 1988

\author{
J. M. Savinell \\ G. M. Lee \\ Bernhard O. Palsson (corresponding author) \\ Department of Chemical Engineering \\ Herbert H. Dow Building \\ University of Michigan \\ Ann Arbor, MI 48109 \\ USA
}

